\title{
The structure of Attempted Crimes: Cross Border positions of India, U.S.A and the U.K
}

\author{
Souvik Roy, N.K. Chakrabarti, Bhupal Bhattacharya
}

\begin{abstract}
For engaging in a productive comparison among the jurisprudences of India, UK and the USA, a level of abstraction must be reached which makes possible the commensuration of the doctrinal discussion created in all these three contexts. In the sphere of the theory of criminal law, such a shared scheme of concept can be obtained in the extensively recognised difference among the three sets of legal standards or rules, which feasible for entering in the depth of the language game of attributing the basis of criminal liability.

This article is an attempt at redefining the conception of attempted crimes, based on a logically oriented theory of standards which recognises the deficit of the wrongfulness of the behaviour imputable to the agent as its distinguishing spot. This type of offence imperfection is described as a dearth of complete performative similarity within the objective configuration of the behaviour of the agent and its value of decoration. A majority of the universal law crimes make the involvement of actual harm to property or person. For this reason, manslaughter, murder, mayhem, rape and robbery have the requirement of hurting to the individual whereas arson have the requirement of harm to real larceny and property, harm to personal property.

In contrast to this, in some universal law, crimes might be carried out even though there is no harm except the threat of harm. Solicitation for committing a felony is a criminal act though the individual becomes failure in committing it.

This article shall analyses the cases which relate to the different types of criminal attempts in the countries of India, the United Kingdom and the United States of America with reference to the criminal laws in the respective countries. The entire research shall be carried out assessing a total of almost ten to eleven cases of attempted crimes.
\end{abstract}

Index Terms: Attempted Crimes; forms of Crimes; Crime Statistics; Criminalising action.

\section{INTRODUCTION}

The statistics are affected by both statistical and legal factors, and by the degree to which the criminal activities are registered and reported. These factors may differ from one nation to another nation. There do not exist any global norms for the production and presentation of crime statistics and this makes the global comparisons very complicated.

The legal aspects which affect the statistics of crime comprise of the way in which the offensive acts are described in the pertinent jurisdiction, for instance, in addition to the guiding principles and rules that get for the task of the prosecutors and the police. The statistical aspects influences comprising of the

Revised Manuscript Received on October 25, 2019.

Mr. Souvik Roy, Assistant Professor-II, KIIT School of Law-Bhubaneswar, India.

Prof.Dr. N.K. Chakrabarti, Vice-Chancellor, WBNUJS- Kolkata, India.

Dr.Bhupal Bhattacharya, Assistant Professor-III, Amity Law School, Amity University Kolkata, West Bengal, India. principles which decide when a criminal activity is documented in the statistics.

In a number of jurisdictions, a case is only registered if it is capable of being taken into legitimate consideration as a crime subsequent to the completion of investigation.

\section{DISCUSSION}

Solicitation, conspiracy and attempts are all taken into consideration as inchoate crimes. The term 'inchoate' refers to just started, incipient, in the initial phases. Inchoate criminal activities may be left incomplete or unaccomplished. Even though criminal attempts never lead to the completion of the illegal offensive acts, both solicitation and conspiracy are capable of giving rise to distinct criminal activities.

The logic which supports punishment for an inchoate criminal activity is deterrence and prevention. If an accused person cannot be apprehended until the completion of a criminal activity, the enforcement of law would not be capable of intervening and averting damage to the property or the victims. Along with this, an accused person who is not capable of completing a criminal activity would attempt over and over, free from any kind of legal punishment.

The complicatedness in holding an accused individual responsible for an incomplete or inchoate criminal activity is ascertaining the extent of development required for the imputation of criminal accountability that is in particular intimidating with attempt, for the reason that in every case, the illegal action is left unaccomplished. The test of proximity computes the progress of the accused individual towards the completion of the offensive act.

The statutes of general attempt lay down the components of criminal attempt and make them applicable to any illegal action. The particular statutes of attempt describe attempt in accord with the specified criminal activities, for example attempted rape, robbery or murder. The tests which are used are used by the criminal law for the purpose of ascertaining the element of criminal act stresses on the necessity for attempt which is proximate for probable desistance, such as res ipsa loquitur, and so on. The test of equivocality or res ipsa loquitur evaluates the actions of the accused person at a particular point of time for the determination of whether he or she had no other intent than the commitment of that illegal action. The test of probable desistance assesses whether the accused individual has gone so far that it is possible he or she will not discontinue without intervention from the enforcement of law or other circumstances of intervention. 


\section{The structure of Attempted Crimes: Cross Border positions of India, U.S.A and the U.K}

The preparatory criminal actions criminalise the preparation of committing an illegal action that would be a phase which is very untimely for the constitution of the element of criminal activity essential for attempt. The element of criminal intention is essential for attempt in particular with the specific purpose of committing the crime.

\section{CASES FROM INDIA}

In the case of Abhayanand Mishra v. State of Bihar, Abhayanand Mishra had the intention of deceiving the Patna University in obtaining the required permission in making addition in the admission card. He, not only sent an application form for obtaining the authorization for sitting at the examination of the University, but followed it up as well. After receiving the required authorisation, he remitted the required fees and sent his photographed copies, and after receiving these documents from the appellant, the University of Patna issued him the admit card. For this reason, there is almost no scope for stating that the deeds which were conducted by the defendant individual, Abhayanand Mishra in actual fact did not add up to his trying for the commission of the criminal action and did not go ahead of the level of preparation. The preparation was finished when he had made the completed his initial level of steps and submitted an application to the University of Patna. The time when he sent it off, he made entry into the area of making an attempt for the commission of the criminal action of 'cheating'. He turned out to be successful in lying to the University and tempting it to make the issuance of the admit card. He did not become successful to get it and appear in the examination of University for the reason that something ahead of his authority happened as the concerned authorities in the University came to know about his being neither a teacher nor a graduate. For this reason, it is concluded that Abhayanand Mishra has been correctly accused and identified for the illegal activity of cheating under section 420, read with section 511 of Indian Penal Code, and the appeal was dismissed accordingly. In order for making up 'an illegal effort', first, there has to be an intent for carrying out a specific illegal activity, second, a few actions should have been conducted which would essentially have to be conducted in the direction of the conduction of the criminal action, and, third, this kind of action has to be close to the planned outcome $^{1}$. The calculation of proximity is not in association with action and time even though it has association with intent. In alternative statements, the action has to disclose, with practical confidence, in addition to other circumstances and facts and not essentially in separation, intent, as notable from a sheer object or desire, for carrying out the specific criminal action, although the activity by itself might be simply indicative or suggestive of such intent. However, it should be construed as suggestive or indicative of the intent. For example, in the case of State of Maharashtra v. Md. Yakub and others, if the lorry been halted and searched at the very beginning of the trip or even at Shirsad Naka, the silver bars that the truck was carrying might have been found which would have revealed that the defendant persons were preparing or had prepared for the conduction of the illegal activity. It can be held that the defendant individuals attempted to transport or were transporting the silver bars to some place even though it would not essentially indicate or suggest that the intent was exporting the silver bars. The evidence that the lorry was taken up to an abandoned cove from where the silver bars could be moved into a seafaring ship was indicative or suggestive although this cannot be concluded, that the defendant person desired to sell the silver bars abroad. It may have been open to the defendant person for pleading that the silver bars were not to be sold abroad but only to be transported in the course of inter coastal trade. As a result of this, the appeal was also dismissed.

\section{CASES FROM THE UK}

If a person conducts any activity that is more than just the stage of preparation to the commission of the illegal action with the aim of carrying out a criminal activity, then he or she is culpable for the illegal effort of carrying out the illegal activity. An individual may be culpable of the criminal effort of carrying out an illegal activity to which this sector is appropriate although the fact is such that the procedure of carrying out the criminal action is not feasible at all. In any case in which the purpose of an individual will not be taken into account as having added to a purpose of carrying out an illegal activity; even though if the facts of the case were analogous to his or her considerations with regards to them, his or her purpose would be taken into regard, then, he or she will be taken into consideration as having had a purpose of carrying out that criminal action. According to law, in the proceedings in opposition to a person for an illegal action, there is adequate confirmation for sustaining a discovery that he or she has carried out that action. The case of Regina $v$. Shivpuri ([1986] 1 All ER 334) is a House of Lords case guided by the British Law, on the topic of whether a criminal action which is impossible to commit can be brought under the purview of criminal liability. The issue framed before the Criminal Division of Appellate Court was whether an individual carrying out an illegal activity under section 1 of the Criminal Attempts Act 1981 in which, if the facts were as that individual believed them to be, the entire criminal activity would have been carried out by him, even though on the actual facts the criminal action which that individual set out for carrying out was not possible according to law, for example, for the reason that the material imported and considered to be heroin was not heroin even though a risk free material. In the instant case, the accused was charged for importation of controlled substances (drugs) for which he had the requisite intention but as it turned out, the substance that he carried was actually not drugs. Hence, the impossibility to commit the offence as a defence was turned down by the court of law and thereby liability was upheld. 
The case of $R$ v. Whybrow ((1951) 35 Cr.App.R. 141 (C.C.A.).) is really vital in its instantaneous impressions. The purpose of the murder is sufficient enough for the attempt of killing. This sets up a substantially greater load of evidence for the Mens Rea of attempt of killing than for killing in reality, making charges for killing much higher. Thus, the point of malice aforethought is very relevant and material when it to culpability pertaining to such crimes. In contrast to this, it concludes that, anyone who is culpable for the attempt of grievous bodily harms or grievous bodily harms with purpose inevitably turning out to be blamed for attempt of murder as an outcome of the overlapping necessities of those illegal actions. This will be a strange state of affairs in law for making someone instantaneously blame worthy of a further crucial criminal activity than was fundamentally lodged upon by purpose of the coincidence of the process of interaction of the law on illegal efforts with the law on deadly illegal actions. It is usually not fair for making a person inevitably blameworthy of an illegal activity that is much more critical, if not in association with possible chastisements, but in association with probably actual sentences and in association with the substantial additional social humiliation that will be entailed. This would speciously have the necessity that a respondent individual would have the obligation and the purpose of bringing about the final result of the finished misdemeanour. Further, it would have also the necessity of comprising all the elements of the illegal action inside its scope, as the outcome of rape is not just sexual interaction, although the sexual interaction which has been carried out devoid of the consensus of the woman. The case of $R v$. Geddes ((1996) 160 JP 697) is very important in defining the undesirable way which is an outcome of the imaginary hazard of the consequence. A traitorous paedophile who was wholly organized for kidnapping kids, faces no result of his actions. On the contrary, this result is the typical inference of the actions of a court enduring by a realistic instead of purposive construction of the Criminal Attempts and trailing the spirit of previous cases as to the height of establishing the evidential bar. As an outcome of this, it helps as a significant illustration for the people who desire for a further purposive or subjective approach which appreciates the legislation much compliantly so as for the acceptance of a lower border line for accountability to be perpetrated. As an outcome of this, Geddes is a very significant case that depicts the further risky faults in the literal understanding of the law. All the five cases described above are quite important in the development of the law in their own characteristic styles. The case of Geddes has advocated the courts for tracking a literal understanding of the Actus Reus of the illegal action and created the conditions which view the things that can be undoubtedly obtained from the matter that is a matter of fact which can be confronted before the courts of law. The case of Whybrow has definitely set up an important instance on the Mens Rea of the attempt of killing and by itself. It has also circumvented that numbers of unfriendly acts in miscarriages of justice are in practice, some of which have disclosed many noteworthy principles which have the requirement of being said to be appropriate in developing various thoughts of the ideal nature of Mens Rea of an illegal effort. The case of Khan has made the Mens Rea of illegal efforts a bit complex as an outcome of the model that has been set by it. It has ostensibly managed for encroaching upon the principle which an illegal effort indicates that is necessary for attempting the result of the finished criminal activity. The most significant case of $R v$. Shivpuri ([1986] 2 All ER 334) is extremely imperative which deals with the likelihood of attempting an act as much as the case of Geddes, which is one of the leading cases of illegal effort. It gives the depiction of the potential inconsistency which is capable of being the outcome of the development of the criminal law from being factual to the particular. There are very few other cases that are capable of claiming to give this kind of an impact on the law as the former cases, and as a consequence of this, these 5 distinguishing cases are the most remarkable on the development of the law on illegal attempts.

\section{CASES From the USA}

In the case of State v. Gillette, the implications of executing transferred purpose to the attempt of murder, which is certainly a crime for its purpose and significance. The conviction of Gillette attempted to frame an opinion of an individual devoid of any verification of particular purpose that is opposite of the extremely essential proof of particular purpose in illegal efforts. If Gillette had the certain purpose of murdering Westbrook and Erdmann, the court would not have found it crucial for executing the policy of transferred purpose. The usage of transferred purpose by the court was an admittance of the non existence of the certain purpose of Gillette for the assassination of Westbrook and Erdmann. The procedure of getting a certain purpose is indispensable for an opinion of the attempt of murder. On the other hand, the conduct of a reckless Gillette was, free from a certain purpose to assassinate Westbrook and Erdmann, and for this cause, he was not convicted for the attempt of murder. The court was of the view that it cannot be deduced that Gillette had the purpose of assassinating only one person, but also had the purpose of assassinating all other individuals who were inside the boundary of danger. This expands the culpability for illegal effort in which there is no logicality of the victims in which the indicted individual does not have any certain purpose of assassination. It cannot be confirmed that Gillette had the knowledge of the incidence of Westbrook and Erdmann. As an outcome of this, he could not have had the certain purpose of assassinating them. The assessment of the court in the case of Gillette alleviates the burden of proving on the state in establishing the illegal efforts. This shifts the burden of confirmation from the state to the accused person, in taking his defence. The Court of Appeals in New Mexico framed universally a new set of guidelines for shifted purpose.The effect of this judgment is to disprove the substantiation of the certain purpose of the criminal attempt into criminal action with a certain criminal purpose. In the case of Thomas, when the court had to deal with the problematic choice between legal or factual impossibility, it did away with the confrontation of legal impossibility in the other segment that is, the completion of the premeditated illegal action is turned into impractical as an outcome of a few rules of law. 


\section{The structure of Attempted Crimes: Cross Border positions of India, U.S.A and the U.K}

The Court of Military Appeals in the United States of America was entirely reliant upon the Model Penal Code, a basic enactment made by the American Law Institute which is free from all the obligation of law and not been challenged by any of the parties.In fact, the Model Penal Code to a certain extent disposes off the resistance of legal impossibility in order, for the set back of the consequences in cases where the accusations of the illegal efforts have been left behind based on the fact that it was legitimately not feasible for the criminal to have completed the illegal action in consideration. It can be said otherwise, the Model Penal Code states that the confrontation is easy to get just in the initial segment, to be exact; the premeditated consequence is not a criminal activity. The Code offers the rationalization of the elimination of the second segment. The achievement of the premeditated criminal activity is turned into unfeasible as an outcome of a few rules of law on the supposition that criminal intention has been noticeably recognized, the criminal has tried to execute the rationale in accord with his best possible attempt. For this reason, his "terribleness" has been palpable.

With no respect to the potency of the negative response of the Code with respect to this group of legal impossibilities, it gives the impression that the court founded its negative response on the things which was taken by it into account to be a disappointing incomprehension in existing authority and the resulting defiance of true as well as momentous justice. The court was conscientious in citing a large number of the consequential cases and authorities in the field of illegal efforts.

On the other hand, the outlook of the majority opinion did not take care of the limited field of the attempt of rape to be precise, even though sought for matching all the cases of illegal efforts. Even though the court was of the view that the discrepancy between factual and legal impossibility is blurred, the authorities do not support this analysis. By basing its verdict upon the Model Penal Code, the court preferred not to base its judgment on the basis of factual and legal impossibility. If the court had taken the case, the factual impossibility would have been given due priority in overcoming the condition of legal impossibility. In comparison to this, had the court had recognised the negative response of the lawful impossibility, it would have put just very little punishment into operation even though the indicted individual had a foul purpose of carrying out a horrifying illegal activity. In addition to this, the court would have disagreed with the proposition that the sentence of an individual who has recognized his seriousness is warranted for the protection of all female people and not just the injured party to be precise. At long last, it can be said that this outlook of the case would have been the same to the negative response of the well acknowledged test of "sensible man". It has been concluded from the analyses of the cases that an illegal effort brings in something that is carried on in the route of the accomplishment of an alleged intention to succeed. An illegal effort in carrying out an illegal activity is not a complete attempt made by a few actions with an illegal intent. The purpose of the defendant person can exclusively be visibly decided by the steps that he has carried on for accomplishing his plan. The unlawful distinguishing feature of a criminal activity is a conclusion of law derived from the state of affairs and the details of the case. As an outcome of this, in an endeavour of carrying out an illegal activity, the words and the acts of the accused person are extremely significant components for making up a criminal activity, and revealing the intention that was in sight. The term "criminal effort" is used in the law in most of the cases in carrying out a criminal act even though it has no practical significance for the techniques used with the object and purpose.

An assault is an effort of doing some personal violence to another individual, and the term "assault" has attained a technical connotation which imports an indictment of deliberate wrong demeanour and aggression. This positive technical implication of the term renders it to be laid off, in an indictment for an assault with the purpose of carrying out an illegal action.

The feature of the illegal action, has brought about the authorization of a number of laws in England and the United States of America, setting forth, in express terms, what actions shall be constituted as an illegal effort for carrying out the illegal actions referred to in these kinds of laws. In an event not particularly described, the illegal action of a criminal effort for committing a criminal activity, even though declared, in a decree as a criminal activity, stays as at universal law, in general terms.

\section{Conclusion}

The above article concludes that each and every nation has its own standards regarding the defining criminal attempts as a criminal act. The methods of measuring the crime differ from one nation to another nation. The statistical categorisations of various kinds of events differ. The criminal attempts are influenced by the willingness of the people for reporting crime and by the efforts made by the legal authorities for dealing with reported criminal acts in the light of the manner in which they prioritise various kinds of offensive acts. This can also differ from nation to nation, making global comparisons further complicated.

\section{REFERENCES}

1. Albanese, J. S. (2014). Organized crime in our times. Routledge.

2. Alicke, M. D. (2000). Culpable control and the psychology of blame. Psychological bulletin, 126(4), 556

3. Arenson, K. J. (2005). The pitfalls in the law of attempt: a new perspective. The Journal of Criminal Law, 69(2), 146-167.

4. Arnold, T. W. (1930). Criminal Attempts. The Rise and Fall of an Abstraction. The Yale Law Journal, 40(1), 53-80.

5. Ashworth, A. (1987). Criminal Attempts and the Role of Resulting Harm under the Code, and in the Common Law. Rutgers LJ, 19, 725.

6. Ashworth, A. (2015). Sentencing and criminal justice. Cambridge University Press.

7. Ashworth, A., \&Horder, J. (2013). Principles of criminal law. Oxford University Press.

8. BARNEY, J., \&Schmidtz, D. (2018). BEHIND EVERY GREAT FORTUNE IS ANEQUALLY GREAT CRIME. Capitalism Beyond Mutuality?: Perspectives Integrating Philosophy and Social Science.

9. Bassiouni, M. C. (1980). International criminal law: A draft international criminal code. Brill Archive.

10. Batey, R. (2004). Minority Report and the Law of Attempt. Ohio St. J. Crim. L., 1, 689 .
Published By: Blue Eyes Intelligence Engineering \& Sciences Publication 
11. Beale Jr, J. H. (1904). The Development of Jurisprudence During the Past Century. Harv. L. Rev., 18, 271.

12. Ben-Shahar, O., \&Harel, A. (1996). Economics of the law of criminal attempts: A victim-centered perspective. U. Pa. L. Rev., 145, 299.

13. Chambliss, W. J. (1964). A sociological analysis of the law of vagrancy. Soc. Probs., 12, 67.

14. Cusack, C. M. (2017). Animals and Criminal Justice. Routledge.

15. Davis, K. C. (1970). The Liberalized Law of Standing. The University of Chicago Law Review, 37(3), 450-473.

16. Dishman, C. (2005). The leaderless nexus: When crime and terror converge. Studies in Conflict \& Terrorism, 28(3), 237-252.

17. Elsbach, K. D., \& Sutton, R. I. (1992). Acquiring organizational legitimacy through illegitimate actions: A marriage of institutional and impression management theories. Academy of management Journal, 35(4), 699-738.

18. Farrell, G. (2016). Attempted crime and the crime drop. Internationa Criminal Justice Review, 26(1), 21-30.

19. Felson, M. (2006). Crime and nature. Sage.

20. Ferguson, P. R. (2013). Moving from Preparation to Perpetration-Attempted Crimes and Breach of the Peace in Scots Law. Ohio St. J. Crim. L., 11, 687.

21. Funston, B. (1965). Attempted Crimes under the Doctrine of Impossibility and the Role of the Judge in Shaping Future Legislation. Tulsa LJ, 2, 161.

22. Funston, B., 1965. Attempted Crimes under the Doctrine of Impossibility and the Role of the Judge in Shaping Future

23. Gabor, T. (1990). Crime displacement and situational prevention: Toward the development of some principles. Canadian $J$. Criminology, 32, 41 .

24. Gaines, L. K., \& Miller, R. L. (2008). Criminal justice in action.

25. Garton, N. (1973). The Actus Reus in Criminal Attempts. Queen's $L J, 2,183$.

26. Greenwood, P. W., \& PETERSIUA, J. (1975). THE CRIMINAL INVESTIGATION PROCESS VOLUME I: SUMMARY AND POLICY IMPUCATIONS

27. Jacobsen, K., \& Landau, L. B. (2003). The dual imperative in refugee research: some methodological and ethical considerations in social science research on forced migration. Disasters, 27(3), 185-206.

28. Jescheck, H. H. (1975). The doctrine of mens rea in German criminal law-its historical background and present state. Comp. \& Int'l LJS Afr., 8, 112 .

29. Joseph, V. G. (1996). Reforming the Law Relating to Attempt: A Proposal. Student Advoc., 8, 37.

30. Joyce, R. (2007). The evolution of morality. MIT press

31. Kadish, S. H., Schulhofer, S. J., \&Barkow, R. E. (2016). Criminal law Business.

32. Kelman, H. C., \& Hamilton, V. L. (1989). Crimes of obedience Toward a social psychology of authority and responsibility. Yale University Press.

33. Kritchevsky, B. (1997). Criminal Attempt-Murder Two: The Law in Tennessee after State v. Kimbrough. U. Mem. L. Rev., 28, 3.

34. Kritz, N. J. (Ed.). (1995). Transitional justice: how emerging democracies reckon with former regimes (Vol. 2). US Institute of Peace Press.

35. LaCroix, A. (2007). Attempted Online Child Enticement: Not Impossible, but Not That Simple. Dartmouth LJ, 5, 97.

36. Miles, M. B., Huberman, A. M., Huberman, M. A., \& Huberman, M. (1994). Qualitative data analysis: An expanded sourcebook. sage.

37. Mirandé, A. (2011). Rascuache Lawyer: A Paradigm of Ordinary Litigation. U. Miami Race \& Soc. Just. L. Rev., 1, 155.

38. Ohana, D., 2007. Desert and Punishment for Acts Preparatory to the Commission of a Crime. Canadian Journal of Law \& Jurisprudence, 20(1), pp.113-142.

39. Packer, H. (1968). The limits of the criminal sanction. Stanford University Press.

40. Pager, D. (2008). Marked: Race, crime, and finding work in an era of mass incarceration. University of Chicago Press.

41. Prendergast, D. (2015). A Philosophy of Criminal Attempts.

42. Rodrik, D. (2004). Industrial policy for the twenty-first century.

43. Rohr, J. (2017). Ethics for bureaucrats: An essay on law and values. Routledge.

44. Schulhofer, S. J. (1974). Harm and punishment: A critique of emphasis on the results of conduct in the criminal law. University of Legislation. Tulsa LJ, 2, p.161. Nelson Education. and its processes: Cases and materials. Wolters Kluwer Law \& Pennsylvania Law Review, 122(6), 1497-1607.

45. Shue, T. (1979). Attempting to Define an Attempt-Of Method and Substance. Malaya L. Rev., 21, 128.

46. Sim, P. B. A. (1955). The Actus Reus in Criminal Attempts. The Modern Law Review, 18(6), 620-623.

47. Skilton, R. H. (1936). The Requisite Act in a Criminal Attempt. $U$. Pitt. L. Rev., 3, 308

48. Skogan, W. G. (1992). Disorder and decline: Crime and the spiral of decay in American neighborhoods. Univ of California Press.

49. Slaughter, A. M. (2009). A new world order. Princeton University Press.

50. Smith, K. J. M. (1998). An Objectivist's Account of Criminal Attempts. Mod. L. Rev., 61, 438.

51. Summers, M. A. (2003). The International Court of Justice's Decision in Congo v. Belgium: How Has It Affected the Development of a Principle of Universal Jurisdiction That Would Obligate All States to Prosecute War Criminals. BU Int'l LJ, 21, 63

52. Väyrynen, R., 2005. Illegal immigration, human trafficking and organized crime. In Poverty, international migration and asylum (pp 143-170). Palgrave Macmillan, London.

53. Waite, J. B. (1955). Judges and the Crime Burden. Mich. L. Rev., 54, 169.

54. Wechsler, H., Jones, W. K., \& Korn, H. L. (1961). The Treatment of Inchoate Crimes in the Model Penal Code of the American Law Institute: Attempt, Solicitation, and Conspiracy. Colum. L. Rev., 61 957

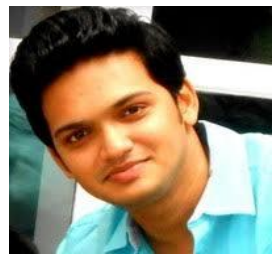

\section{AUTHORS PROFILE}

Souvik is currently a Ph.D research scholar at School of Law, KIIT (Deemed to be University) where he is also working an Assistant Professor-II. Prior to that, he was working as an Assistant Professor at National Law University, Odisha (NLUO) for almost three years not before working with PDS \& Associates Law Firm in Mumbai. He completed is B.A.LL.B from University of Calcutta, Department of Law followed by LL.M with Merit (First Class and Distinction in couple of disciplines) from University of London for which he was the recipient a scholarship as well from University of Calcutta

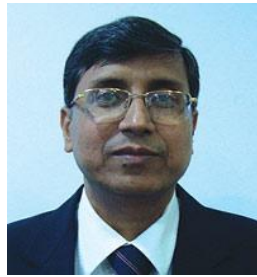

Prof. Dr. N.K. Chakrabarti, Currently, the Vice-Chancellor of WBNUJS, Kolkata ,Prof. Chakrabarti has published more than 80 articles and research papers in various national and international journals such as International Journal of Comparative Criminology and Offender Therapy, New York, International Journal of Legislative Drafting and Law Reform, London, Journal of Biological and Clinical Antropology, Germany, Scholars International Journal of Law, Crime and Justice, Dubai, and among National Journals- Journal of Indian Law Institute, A.I.R., Criminal Law Journal, Indian Journal of Criminology, Journal of Indian Academy of Social Science, Calcutta Law Times, KIIT Journal of Law and Society etc. He was Faculty of Law at University of Calcutta and later, the Director of School of Law, KIIT (Deemed to be University) for a period of 10 years prior to his current assignment at WBNUJS.

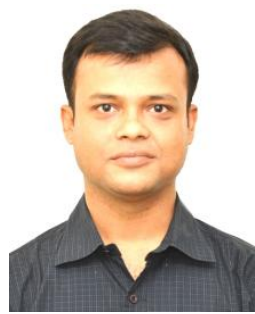

Dr. Bhupal Bhattacharya is presently associated with Amity Law School, Amity University Kolkata as a Faculty member. He has more than 9.5 years of academic experience in different institutions including Banasthali Vidyapith, NIT Durgapur, Amity University Mumbai, Sikkim Manipal University, etc., in addition to 2 years of industria experience. He has completed his B.com (Hons.), LL.M, MSW and his Ph.D. in Law. He is in the editorial boards of many national and international Journals. He has to his credits four books published (two from Indian Publishers and rest other two from an Australian Publisher) in addition to few published research papers in various Scopus indexed international journals

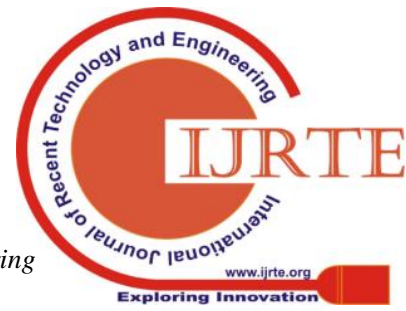

